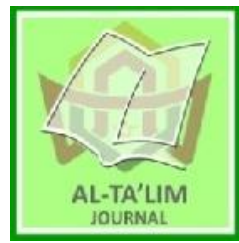

AL-TA'LIM JOURNAL, 27 (1), 2020, (80-91)

(Print ISSN 1410-7546 Online ISSN 2355-7893)

Available online at http://journal.tarbiyahiainib.ac.id/index.php/attalim

\title{
Teachers' Code Mixing and Code Switching: Insights on Language Barriers in EFL Classroom
}

Received: $19^{\text {th }}$ January 2020; Revised: $06^{\text {th }}$ February 2020; Accepted: $25^{\text {th }}$ February 2020

Permalink/DOI: http://dx.doi.org/10.15548/it.v27i1.606

\section{Rafqi Awlia Siddiq*)}

Universitas Islam Negeri Imam Bonjol Padang, Indonesia.

E-mail: rafqi_awlia@yahoo.com

\section{Martin Kustati}

Universitas Islam Negeri Imam Bonjol Padang, Indonesia

E-mail martinkustati@uinib.ac.id

\section{Luli Sari Yustina}

Universitas Islam Negeri Imam Bonjol Padang, Indonesia.

E-mail: $\underline{\text { ulisariyustina@uinib.ac.id }}$

\section{*) Corresponding Author}

\begin{abstract}
This study aims to investigate code mixing and code switching used by English teachers in EFL classrooms. There are two major focuses in this study; the type of dominant code mixing and code switching used by the teachers. A qualitative study was used where the data were teachers' language classroom gained by observing their classroom practices and utterances obtained through in-depth interviews. The result shows that there were three kinds of code mixing found in teachers' and students' utterances in EFL classroom. They were intra-sentential code mixing, intra-lexical code mixing, and pronunciation shifting. The study also found that there were four kinds of code switching found in teachers' and students' utterances. They were random mixing, English-Indonesian translation or vice versa, English precedes Indonesian or vice versa, and English sentences precede Indonesian sentences or vice versa. It indicated that code mixing and code switching cannot be separated in English language teaching and learning process. This study has proved that the English teachers used code mixing and code switching in teaching speaking in some types.
\end{abstract}

Keywords: Code-mixing; code-switching; EFL classroom

How to Cite: Siddiq, R., Kustati, M., \& Yustina, L.S. (2020). Teachers' Code Mixing and Code Switching: Insights on Language Barriers in EFL Classroom. Al-Ta lim Journal, 27(1). doi:https://doi.org/10.15548/jt.v27i1.606

\section{INTRODUCTION}

Each of the community in the world tries to be able to use the language in their daily communication, including Indonesian people. They should learn the international language as their foreign language. Indonesian government decrees English as one of the school subjects and compulsory subject should be taught from Junior High school up to University (Coleman, 2011; Hawanti, 2014; Lauder, 2010; Mistar, 2005; Pratiwi, 2012; Yulia, 2014). It is hoped by studying English from the early ages, they can master English both written and spoken skills.
In the educational process, the teachers had many contributions to make the goals in English language and discourse competence came true. Students usually acquired English from their teachers' utterances and materials. The English teachers taught and asked the students to practice English in their daily communication. As an ideal classroom discourse is in line with the communicative language teaching principles in which teacher must consistently encourage students to communicate (talk, share, and express ideas) in the target language (Little, 2007; Savignon, 2008, 2018; Tanveer, 2007). 
The implication for education is presumably that the English teacher needs to provide opportunity for students to learn in a way which suits their preferred style of learning. According to Atkinson (2000); Cohen (2010); Dörnyei (2000); Parks \& Guay (2009); Pedersen \& Liu (2003), teacher's motivation and strategies which are given to the students become as the key point to hold that process. There are many strategies to proof and floor it into the class. They are the teacher's choices. The best choices are the appropriate strategies that related to the class and whole of the educational rules.

Teacher's decision to switch the language is influenced by the cultures (Gabillon, 2012). As the focus of the study to Indonesian students who learn English as foreign language, they have many cultures. They also become part of bilingual and multilingual society (Bin Tahir, 2015; Cahyani et al., 2018, 2018; Clyne et al., 2004; Cohn \& Ravindranath, 2014; Hamied, 2012; Kirkpatrick, 2011; Lamb \& Coleman, 2008; Rasman, 2018; Saddhono \& Rohmadi, 2014). The phenomenon of code-switching is found in bilingual and multilingual society, because they are usually required to select a particular code whenever they chose to speak, and they may also switch from one language to another language (Al-Azami, 2006; Kamiya, 2006; Wardhaugh, 2011).

According Wardhaugh (2011), code mixing is two languages used together by the conversant to the extent that they change from one language into another in the course of single utterance. According to Ayeomoni (2006), Baker \& Van den Bogaerde (2008), Bali et al. (2014), Berent (2004), Bernardini \& Schlyter (2004), Genesee \& Nicoladis (2007), Muysken \& Muysken (2000), Van den Bogaerde \& Baker (2005), code-mixing is a symptom of language usage in which a mixing or combination of different variations within the same clause mixed into the code could be called (inner code mixing) if this phenomenon suggests that elements of the relatives in language and if the elements did not interfere it was out (outer code mixing). Code mixing was divided into two categories.
First is inner code-mixing which is derived from the original language with all its variations (formal, standard, informal, nonstandard). Second is foreign outer codemixing, which is derived from languages.

Code switching is the interchangeable used of sentences of two different languages which was an ability to switch from one language to another language (Baker \& Van den Bogaerde, 2008; Berent, 2004). Code switching can be exploited as part of actual teaching methodology. The use of code switching can be due to a kind of a language variation found in a society of bilingual or multilingual speakers. Bilingual teachers commonly used two languages to teach the students in the classroom, especially while English teachers were teaching. They switched between the languages in at least three ways; spontaneously, for direct translation intentionally (Barent, 2004).

West Sumatera is well-known as multilingual society. There were many districts, sub districts, and small areas in this province. Each of the area consists of different society, cultures and languages. When learning English, they attempt to change their mind from their Minang language or their vernacular language into English. In other word, they move from Minang language into English as a foreign language. Within this linguistic chain, the interferences of first language exist. In short, the language change happens, although the form of the language takes place in syntactical, grammatical or lexical level. Based preliminary observation in Junior School 14 Padang, many students, teachers, as well as the staffs acknowledged that they experienced with language interferences. In the learning process, teachers and students were taken along with their first language, sometimes used formal language such as Indonesia or English, in the same time they used their first language (Hawanti, 2014).

Sociolinguistic approach is relevant to explain the reasons to use code switching in society. School is a dominant place for a society to make an interaction. The members 
of school interact to convey ideas, thought and sympathy with others. As members of the school, the teachers and the students are possible to switch their language, while they are communicating each other.

Code mixing and code switching are not only a matter of mixing of two particular languages; speakers are also required to acquire sophisticated knowledge of both languages and cross cultural communication norms. Therefore, those engage in code mixing and switching were acquire both languages. Junior High School 14 Padang has the classes from seventh to tenth grades that have implemented National Standard School programs. To encourage learning process, each of the classes may use some medium such as Projector, Sound systems and also computer.

Teaching English as foreign language in some schools was not an easy matter. One of the problems was the used of English as the medium of instruction in delivering the materials (Lamb \& Coleman, 2014). At the Pioneering Standard School in which teaching and learning process was not yet fully conducted in English. Therefore, was not using English entirely in delivering the material in the classroom causes code switching.

We chose Junior High School 14 Padang as an object in the study to determine how English dominantly used by the English teachers while they were teaching their students in the classroom. There were some reasons why we focus on teacher's code mixing and code switching in teaching speaking at Junior High School 14 Padang. First reason is whole of the educational process successes based on teacher's ways to speak and persuade students brave to speak also. Then, the other reason is the students should master the speaking skill as main realization of language skill and the appropriate teacher's ways could enhance students English speaking skill.

We paid more attention on which one of code mixing and code switching did the teacher prefer to use in teaching speaking and why the teacher used that kind. The teachers in Junior High School 14 Padang switched their language based on the condition of the teachers themselves and also based on students' capability in English.

Based on the observation in the preliminary study, majority of the teachers used English to open the class, such as to greet the students and have a brainstorming session. In learning process, the teachers usually switched the language to Indonesian and also combine with Minang language in some conditions. The teachers combined English words or sentences with those of Indonesian, in four ways of code switching, regarded as the types of code switching used as medium by the teaches in classroom. They were random mixing, English-Indonesian translation or vice versa, English precedes Indonesian or vice versa, and also English sentences precede Indonesian sentences or vice versa. Besides that, there were some kinds of code mixing that usually used by the teacher; they were; intra-lexical code mixing, intra-sentential switching/ code mixing, and also involving a change pronunciation. The use of code mixing and code switching were based on some reasons, such as to build the efficiency of class management, making jokes, clarifying the speech content, and increase student's comprehension and also to explain the lesson.

It is usual for non-native EFL teacher to used code switching and or code mixing as a medium of instruction due to a number of factors such as inadequate oral ability of the teachers, complexity level of teaching topics, curriculum and poor Basic English of the students. However it is unusual if the teacher of good spoken language maximizes if not always use code switching for most of the time during instruction.

Code mixing and code switching becomes the factor of "individual preferences" as their reason why teachers of great oral ability favor to use code mixing and code switching during classroom instruction like those of lower or inadequate oral ability 
users of English. In English teaching, the teacher always uses the simple words and sentences to make the students understand and can practice it well. Thus, the aim of the study is to identify the types of code mixing and switching that mostly used by English teacher at EFL classroom in Secondary school.

\section{METHOD}

A qualitative research design was used where the data taken from observation and interview in EFL classroom in form of written or oral forms. In other words, this method is based on the phenomena that evidence had been taken from the situation of the object. This design was used to understand the meaning behind certain object or situation.

\section{Participants}

The English teachers become the main participants of the study because they direct the teaching activities. In order to investigate the use of code mixing and code switching in Junior High School 14 Padang, we choose two teachers from many English teachers in Junior High School 14 Padang. The teachers had been teaching English at grade VIII junior high school 14 Padang for more than 10 years. They mixed and switched codes among Minang, Indonesian, and English languages.

\section{Research Context}

The research was held a tight grade of Junior High Schools 14 Padang. There were 72 students involved in the research. We came into the class observe some less on sand teaching activities that were given by the teachers. Observations were held for three times. The processes depend on the times of the subject of the teacher. The interview was held after the observation was done for two times.

\section{Instruments}

The data of this study comprised of three data namely types of code mixing used by the teachers, types of code switching used by the teachers, and also the reasons by the teachers who use code mixing and code switching. The data in this research will be collected through an observation. The researchers also use record voices.

\section{Data Collection}

The data were taken from observations and interviews. Observations were done to monitor the teachers' utterances. We recorded teacher's utterances in teaching speaking in the classroom. After that, to emphasize the data, researcher interviewed the teachers to get their opinions why they used code mixing and code switching.

\section{Data Analysis}

After all of the data were collected, researcher analyzed them through the following steps. Firstly, we listened to the recorders several times and made a detail script about the utterances (use of code mixing and code switching) in teaching activity.

Secondly, we differentiated between the observations data with the interview data. Then, we analyzed the English teachers' utterances related to the types of code mixing and code switching based on observation data. This research was not only to show the teachers' code mixing and code switching, but also to seek the meaning behind code mixing and code switching.

\section{RESULTS AND DISCUSSION}

\section{The Types of Code Mixing of Teachers Dominantly in Teaching Speaking at Junior High School 14 Padang}

The types of code mixing used by the English teachers SMP N 14 Padang can be seen at Table 1 below: 
Table 1. Code Mixing in Teachers' Utterances in Some Contexts of Interactions.

\begin{tabular}{|c|c|c|}
\hline Context & Interaction & Information \\
\hline $\begin{array}{l}\text { When the teachers asked } \\
\text { about the position of } \\
\text { students in curriculum }\end{array}$ & $\begin{array}{l}\text { T: Kita Sekarang Kurtilas, Kan? } \\
\text { S: Yes! } \\
\text { T: Kurtilas itu bagaimana,Student senter atau teacher } \\
\quad \text { senter? } \\
\text { S: Menalar, } \\
\text { T: Student Centerkah atau Teacher Centerkah? } \\
\text { S:Student Center }\end{array}$ & $\begin{array}{l}\text { Intra lexical Code } \\
\text { mixing }\end{array}$ \\
\hline $\begin{array}{l}\text { Teachers asked the } \\
\text { students to give an } \\
\text { example }\end{array}$ & $\begin{array}{l}T: \text { Berikan satu contoh kata sifat. } \\
\text { S: Is . . is } \\
T: \text { Is itu bukan kata sifat. Is itu adalah to be. Kata sifat itu } \\
\quad \text { contohnya, satu Sad, Lazy. Kemudian kata kerja, Verb. } \\
\quad \text { Kata kerjaapa? Berikan contoh dari kata kerja. Siapa yang } \\
\quad \text { bisa? }\end{array}$ & $\begin{array}{l}\text { Intra sentential } \\
\text { switching/ Code } \\
\quad \text { mixing }\end{array}$ \\
\hline $\begin{array}{l}\text { When the teachers asked } \\
\text { about the writer in the } \\
\text { text }\end{array}$ & $\begin{array}{l}\text { T: Sebagai siapa si penulis itu menamakan dirinya? } \\
\text { S: Sebaga isi } M y \\
\text { T: } \text { Iya si } M y\end{array}$ & $\begin{array}{l}\text { Intra lexical } \\
\text { Code mixing }\end{array}$ \\
\hline $\begin{array}{l}\text { When the teachers was } \\
\text { asking about the adjective } \\
\text { in the text }\end{array}$ & $\begin{array}{l}T: \text { Kurtilas itu bagaimana? Student center atau Teacher } \\
\quad \text { center? } \\
T \& S: \text { Student center } \\
T: \text { Lai tau? } \\
S: \text { Apo Buk, Siswa lebih aktif. } \\
T: \text { Tolong kamu cari kata Adjectivenya di dalam text itu, }\end{array}$ & $\begin{array}{l}\text { Intra lexical Code } \\
\text { mixing }\end{array}$ \\
\hline $\begin{array}{l}\text { When the teachers was } \\
\text { asking about the verb in } \\
\text { the text }\end{array}$ & $\begin{array}{l}T: \text { Apa To be yang kita pakai? } \\
\text { S: Am, Is, Are. . } \\
T: \text { Kalau menggunakan Verb, bagaimana? } \\
\text { S: Verb satu, verb two, verb dua } \\
T: \text { Tidak! Dia tidak perlu menggunakan kata kerja bentuk } \\
\quad \text { kedua. Sudah mulai terang? }\end{array}$ & $\begin{array}{l}\text { Intra sentential } \\
\text { switching/ Code } \\
\quad \text { mixing }\end{array}$ \\
\hline $\begin{array}{l}\text { When the teachers was } \\
\text { asking for the material to } \\
\text { be taught }\end{array}$ & $\begin{array}{l}T: \frac{\text { Today, kita akan belajar tentang Present Continuous }}{\text { Tense. Ada yang tahu apa itu Present Continuous Tense? }} \\
S: \text { Ndak Buk! }\end{array}$ & $\begin{array}{l}\text { Intra sentential } \\
\text { switching/ Code } \\
\text { mixing }\end{array}$ \\
\hline $\begin{array}{l}\text { Teachers was asking for } \\
\text { the position word in the } \\
\text { text }\end{array}$ & $\begin{array}{l}T: \text { kata kerja, kata benda, atau kata apadia? Kemudian } \\
\text { studying? Kata benda, kata sifat atau kata kerja? } \\
S: \text { Kata kerja! }\end{array}$ & $\begin{array}{l}\text { Intra sentential } \\
\text { switching/ Code } \\
\text { mixing }\end{array}$ \\
\hline $\begin{array}{l}\text { Teachers was telling } \\
\text { students to complete the } \\
\text { task }\end{array}$ & $\begin{array}{l}T: \text { Bagaimana bunyi kalimatnya? } \\
S \& \text { } T: \text { He is watering the flower } \\
T: \text { Laki-laki itu sedang menyiram bunga. } \\
\text { Sweep the floor } \\
S: \text { Menyapu lantai. } \\
T: \text { Iya, She is sweeping the floor. Silahkan lanjutkan sampai } \\
\quad \text { listen to music! }\end{array}$ & $\begin{array}{l}\text { Intra sentential } \\
\text { switching/ } \\
\text { Code mixing }\end{array}$ \\
\hline $\begin{array}{l}\text { Teachers asked about the } \\
\text { type of text }\end{array}$ & $\begin{aligned} T: & \text { Termasuk kedalam text apa dia? Kalian sudah Ibu } \\
& \text { sebutkan Junior High School di SMP text monolog itu. } \\
& \text { Descriptive text, Narrative text, Recount text, Procedure. } \\
& \text { Nah, Text ini menceritakan tentang rumah. } \\
S: & \text { Descriptive text, Buk. }\end{aligned}$ & $\begin{array}{l}\text { Involving a change } \\
\text { of pronunciation }\end{array}$ \\
\hline
\end{tabular}

From the table 1, it was found that there were50 utterances where they were divided in to nine code mixing happen in the interactions. Based on the classroom setting above, some types of code mixing were salient in teachers' utterances were provided in the following parts.

\section{Intra-Sentential Code Switching/ Code Mixing}

It was found that teachers used intrasentential code switching/ mixing while she said "contohnya, satu Sad, Lazy". This clause was a combination between English 
and Indonesian language. At the second context, one of teachers said "Today, kita akan belajar tentang Present Continuous Tense" in Indonesian utterance and also use Indonesian language "hari ini" in English utterance. In this conversation there were English words among Indonesian words or Indonesian word among English Words. There were some different words from different codes or language to build this clause.

\section{Intra-Lexical Mixing}

At the third context, we found the teachers mix the language within the words; the teachers used this type while they were teaching speaking. This type could see in a word that was consisted of English and Indonesian Language. The words such as $s i$ My,describkannya, Adjectivenya are some of the words in this type that were used.

Each of the words above consisted by two codes, English and followed by Indonesian word-nya and si. The words above added by suffix-nya that come from Indonesian language. In Intra-Lexical Mixing the two codes have been mixed in a word to complete sentences.

\section{Involving a Change of Pronunciation}

This type was used when the teachers taught about kind of text. The teachers mixed the language at phonological level, and mix the modified words. The teachers used words monolog. Monolog as English word has been modified and used by mostly people in
Indonesian. Monolog comes from mono and $\log$.

Among the fifty utterances that are included into the types of code mixing, researcher found 9 utterances of the first-type intra sentential switching are 5 utterances with frequency about $56 \%$ for the second type-intra lexical code mixing- there are 3 utterances with frequency about $33 \%$ and for the third type-involving a change of pronunciation. There is 1utterance with frequency about $11 \%$. Based on the frequencies above were proved that the teachers disposed use the first type of code mixing used by teacher in teaching speaking at Junior High School 14 Padang.

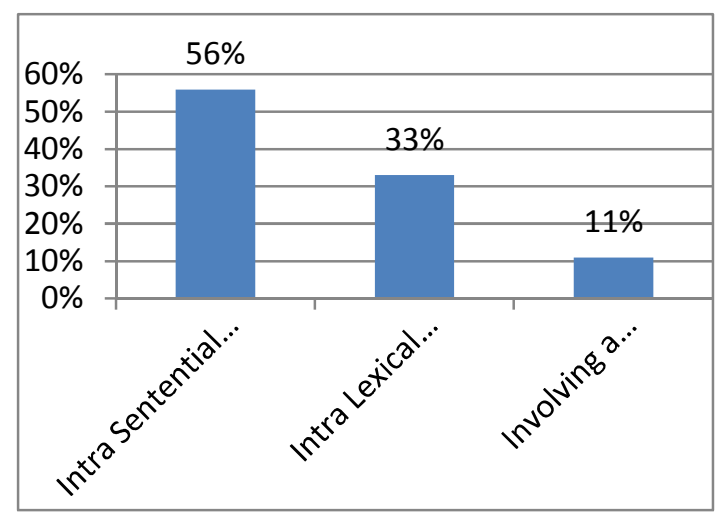

Graphic 1.The Frequencies of Intra-Sentential Code Switching/ Code Mixing

\section{The Types of Code Switching of Teachers Dominantly in Teaching Speaking at Junior High School 14 Padang}

The types of code switching used by the English teacher at EFL classroom are in the following.

Table 2. Code Switching in Teachers' Utterances in Some Contexts of the Interactions.

\begin{tabular}{|c|c|c|}
\hline Context & Interaction & Information \\
\hline $\begin{array}{l}\text { Teachers explained the part of } \\
\text { the house }\end{array}$ & $\begin{array}{l}\text { T: } \text { My house is divided into two floors. My house dibagi } \\
\quad \text { menjadi dua lantai } \\
\text { S: Floors }\end{array}$ & Random mixing \\
\hline $\begin{array}{l}\text { Teachers asked about } \\
\text { adjective }\end{array}$ & $\begin{array}{l}\text { T: Do you know adjective? Apakah kalian tahu tentang } \\
\quad \text { adjective? } \\
\text { S: Lai buk } \\
\text { T: Bagus }\end{array}$ & Random mixing \\
\hline $\begin{array}{l}\text { Teachers asked how to make } \\
\text { something }\end{array}$ & $\begin{array}{l}\text { T: How to make omelet? Bagaimana membuat omelet? } \\
\text { S: Mmmmm. . (bingung) }\end{array}$ & Random mixing \\
\hline
\end{tabular}




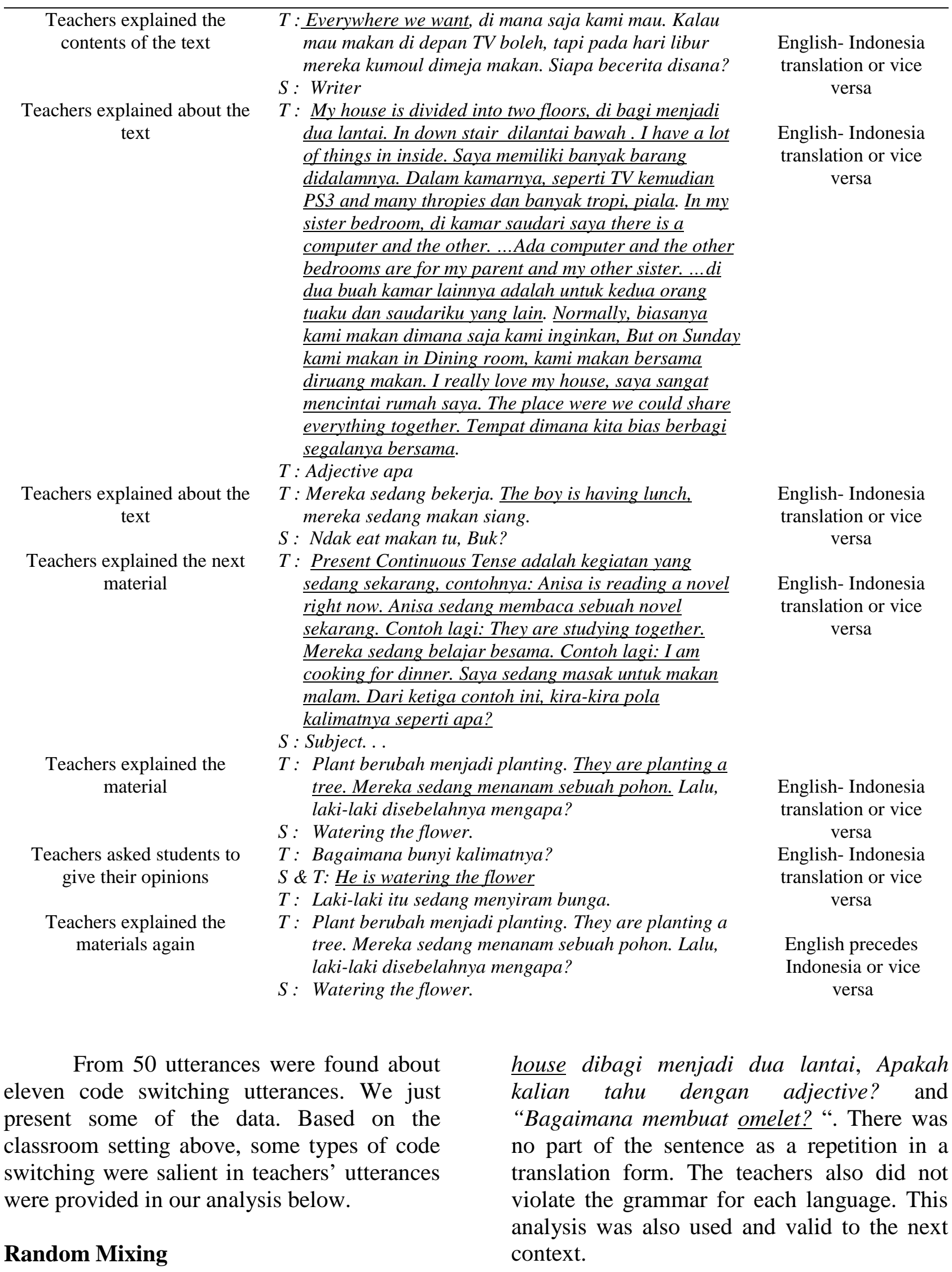

We found the teacher combined the different words within the sentence, the teacher combines Indonesian language; $\underline{M y}$ 


\section{English-Indonesian Translation or Vice Versa}

For the next context of classroom setting researcher found the teachers gave an exercise in the worksheet and help students to practice their daily conversation. The teachers used a combination where on English sentence preceded its translation into Indonesian, or vice versa.

Di mana saja kami mau, this sentence was the translation form of the first sentence which was in English, Everywhere we want. In English-Indonesian Translation or Vice Versa, the teacher translated the English sentence into Indonesian sentence. It was used to emphasize or to strengthen the information that built in the sentence.

This case also could find when the teachers used a translation in sentence; Normally, biasanya kami makan dimana saja kami inginkan, But on Sunday kami makan in Dining room, kami makan bersama diruang makan. As usually in this type the speaker which was the teacher used the sentence diruang makan to emphasize the first information, in Dining room. The teachers used this second type in code switching except at the last meeting.

\section{English Precedes Indonesian or Vice Versa}

The English teachers also used different form of code switching. Researcher found that there was no part in this sentence which was a translation to signal a repetition. One of teachers said some sentences in Indonesian language, and continued the sentences used English; Plant berubah menjadi planting. They are planting a tree. Mereka sedang menanam sebuah pohon. An English sentence precedes an Indonesian sentence or the other way Indonesian sentence precedes an English sentence but for different ideas or intentions.

The types of code switching discussed above show that the use of code switching performed by the teachers of English in classroom setting is for avoiding long pause, telling the meanings of words, and for easy understanding on the part of the students.

\section{English Sentences Precede Indonesian Sentences or Vice Versa}

For the next context, we did not found that. The teacher used the first language to explain the idea of the target language. In other words, the different form in this type was to conclude the first language. Among the ten utterances that were included into the types of code switching found the first typerandom mixing are three utterances with frequency about $30 \%$ (thirty percent). For the second type-English-Indonesian translation or vice versa-were found six utterances with frequency about $60 \%$ (sixty percent).

The third type English precedes Indonesian or vice versa were found 1 (one) utterance with frequency about $10 \%$ (ten percent), and for the fourth type-English sentence precede Indonesian sentences or vice versa-were did not found utterance. Based on the frequencies above were proved that teachers disposed use random mixing, the first type of code switching in teaching in teaching speaking at Junior High School 14 Padang. It is concluded that the type dominantly of code switching used by teacher in Junior High School 14 Padang is English Indonesia translation or vice versa.

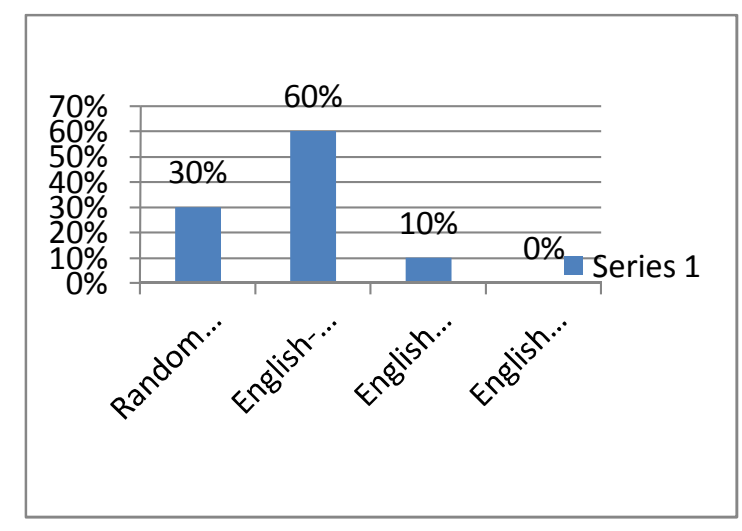

Figure 2. Frequency of English Precedes Indonesian or Vice Versa

Researcher found three kinds of code mixing; intra-sentential switching/code mixing, intra-lexical code mixing, involving a change of pronunciation. There were four kinds of code switching; random maxing, English-Indonesian translation or vice versa, English precedes Indonesian or vice versa, 
and English sentences precede Indonesian sentences or vice versa.

\section{The Types of Code Mixing}

An insertion words in different sentences called as Intra-sentential switching/code mixing as shown in the teacher's utterances; "Today, kita akan belajar tentang Present Continuous Tense." The code mixing occurs within a phrase, a clause or a sentence boundary. The teachers mix to combine their words to give a variation situation in teaching and learning process.

Intra-lexical code mixing, as shown in the teacher's utterances; "Tolong kamu cari kata Adjectivenya di dalam text itu." The code mixing which occurs within a word boundary is intra-lexical code mixing. The last one is the involving a change of pronunciation. The code mixing occurs at the phonological level, as when Indonesian people say an English word, but monolog it to Indonesian phonological structure, as shown as in the sentence; "apa saja jenis monolog teks itu?"

The finding proved the result of the research which conducted by (Adjei \& EwusiMensah, 2019; Akhtar et al., 2016; Ansar, 2017; Pasaribu, n.d.; Waris, 2012) that the teacher dominantly used Intra Sentential Switching/ Code Mixing. Indah (2017) classifies it into words insertion, phrase insertion, repetition insertion, idiom insertion and clause insertion.

\section{The Types of Code Switching}

The combination of different words within a sentence is mostly used by the teacher during teaching and learning process. The teachers mix up English words with Indonesian words in a sentence randomly, Random Mixing, as shown in the insertion of words in the sentence"My house is divided into two floors. My house dibagi menjadi dua lantai."

English Precedes Indonesian or Vice Versa, as shown this situation was shown in the sentences; "Everywhere we want, di mana saja kami mau. Kalau mau makan di depan TV boleh, tapi pada hari libur mereka kumoul dimeja makan. Siapa becerita disana?" An English sentence precedes its translation into Indonesian.

English Precedes Indonesian or Vice Versa, as shown in the sentence; "Plant berubah menjadi planting. They are planting a tree. Mereka sedang menanam sebuah pohon." An English sentence precedes an Indonesian sentence but for different ideas or intentions. This type agree with Hoffman's types of code switching, Establishing Continuity with the Previous Speaker.

English Sentences Precede Indonesian Sentences or Vice Versa, more than one English sentence precedes more than one Indonesian sentence. The teachers dominantly used the second type of code switching. Ansar (2017); Muysken \& Muysken (2000) state English Indonesia translation or vice versa is also called Intra Sentential switching according to Romaine. Teachers used this second type to confirm the principle materials or the significant explanation. To explain the concept well, in order to help the students to comprehend the materials, he teachers automatically change their codes into the first language such in Indonesian language even in Minang language.

\section{CONCLUSIONS AND RECOMMENDATION}

The current study shows that there are several types of code mixing and code switching found in English teachers' and students' utterances in teaching speaking at EFL classroom. Those were intra-sentential code mixing, intra-lexical code mixing, and pronunciation shifting. Meanwhile, there were four kinds of code switching found in teachers' and students' utterances. They are random mixing, English-Indonesian translation or vice versa, English precedes Indonesian or vice versa, and English sentences precede Indonesian sentences or vice versa. In short, it is a way to make the 
communication between teachers and students in EFL classroom are successful and understood in well-manner.

The English teachers are expected to think more critically about the phenomenon in teaching and learning context. From this study, it is found that code switching and code mixing can also be done in teaching and learning process in the classroom. The teachers themselves should improve the research about code switching and code mixing in educational progress.

We are aware of the using of code switching and code mixing can help both of the teachers and the students in teaching and learning English speaking at EFL classroom, especially at secondary EFL classroom schools. Especially to enrich foreign language teaching and learning, hopefully the next researcher can explore the various situations. Besides, the result of this study will also expect to give more information about code switching and code mixing.

\section{REFERENCES}

Adjei, A. A., \& Ewusi-Mensah, L. (2019). Code-Switching And Code-Mixing among University Lecturers In Formal Interactions With Students. Journal of Language and Linguistics, 6.

Akhtar, H., Khan, A., \& Fareed, M. (2016). Code-mixing and code-switching in EFL/ESL context: A sociolinguistic approach. Balochistan Journal of Linguistics, 4, 29-42.

Al-Azami, S. (2006). Linguistic Manipulations in the Bengali Language by the Bangladeshis in Manchester. South Asian Cultural Studies, 1(1), 53-59.

Ansar, F. A. (2017). Code Switching and Code Mixing in Teaching-Learning Process. English Education: Jurnal Tadris Bahasa Inggris, 10(1), 29-45.
Atkinson, E. S. (2000). An investigation into the relationship between teacher motivation and pupil motivation. Educational Psychology, 20(1), 4557.

Ayeomoni, M. O. (2006). Code-switching and code-mixing: Style of language use in childhood in Yoruba speech community. Nordic Journal of African Studies, 15(1).

Baker, A., \& Van den Bogaerde, B. (2008). Code-mixing in signs and words in input to and output from children. Sign Bilingualism: Language Development, Interaction, and Maintenance in Sign Language Contact Situations, 1-27.

Bali, K., Sharma, J., Choudhury, M., \& Vyas, Y. (2014). "I am borrowing ya mixing?" An Analysis of EnglishHindi Code Mixing in Facebook. Proceedings of the First Workshop on Computational Approaches to Code Switching, 116-126.

Berent, G. P. (2004). Sign language-spoken language bilingualism: Code mixing and mode mixing by ASL-English bilinguals. The Handbook of Bilingualism, 312-335.

Bernardini, P., \& Schlyter, S. (2004). Growing syntactic structure and codemixing in the weaker language: The Ivy Hypothesis. Bilingualism: Language and Cognition, 7(1), 49-69.

Bin Tahir, S. Z. (2015). Multilingual behavior of Pesantren IMMIM students in Makassar. Asian EFL Journal, 86, 4564.

Cahyani, H., de Courcy, M., \& Barnett, J. (2018). Teachers' code-switching in bilingual classrooms: Exploring pedagogical and sociocultural functions. International Journal of Bilingual Education and Bilingualism, 21(4), 465-479. 
Clyne, M., Hunt, C. R., \& Isaakidis, T. (2004). Learning a community language as a third language. International Journal of Multilingualism, 1(1), 33-52.

Cohen, A. D. (2010). Focus on the language learner: Styles, strategies and motivation. An Introduction to Applied Linguistics, 2, 161-178.

Cohn, A. C., \& Ravindranath, M. (2014). Local languages in Indonesia: Language maintenance or language shift. Linguistik Indonesia, 32(2), 131-148.

Coleman, H. (2011). Allocating resources for English: The case of Indonesia's English medium international standard schools. Dreams and Realities: Developing Countries and the English Language, 87-111.

Dörnyei, Z. (2000). Motivation in action: Towards a process-oriented conceptualisation of student motivation. British Journal of Educational Psychology, 70(4), 519538.

Gabillon, Z. (2012). Revisiting foreign language teacher beliefs.

Genesee, F., \& Nicoladis, E. (2007). Bilingual first language acquisition. Handbook of Language Development, 324-342.

Hamied, F. A. (2012). English in multicultural and multilingual Indonesian education. In English as an international language in Asia: Implications for language education (pp. 63-78). Springer.

Hawanti, S. (2014). Implementing Indonesia's English language teaching policy in primary schools: The role of teachers' knowledge and beliefs. International Journal of Pedagogies and Learning, 9(2), 162-170.

Indah, R. N. (2017). Critical thinking, writing performance and topic familiarity of
Indonesian EFL learners. Journal of Language Teaching and Research, 8(2), 229-236.

Kamiya, M. (2006). The role of communicative competence in L2 learning. Sophia Junior College Faculty Bulletin, 26, 63-87.

Kirkpatrick, A. (2011). English as an Asian lingua franca and the multilingual model of ELT. Language Teaching, 44(2), 212-224.

Lamb, M., \& Coleman, H. (2008). Literacy in English and the transformation of self and society in post-Soeharto Indonesia. International Journal of Bilingual Education and Bilingualism, 11(2), 189-205.

Lauder, A. (2010). The status and function of English in Indonesia: A review of key factors. Hubs-Asia, 10(1).

Little, D. (2007). Language learner autonomy: Some fundamental considerations revisited. International Journal of Innovation in Language Learning and Teaching, 1(1), 14-29.

Mistar, J. (2005). Teaching English as a foreign language (TEFL) in Indonesia. Teaching English to the World: History, Curriculum, and Practice, 75-85.

Muysken, P., \& Muysken, P. C. (2000). Bilingual speech: A typology of codemixing. Cambridge University Press.

Parks, L., \& Guay, R. P. (2009). Personality, values, and motivation. Personality and Individual Differences, 47(7), 675-684.

Pasaribu, J. F. (n.d.). Code Switching in Teaching English in SMK SwastaTeladan Medan.

Pedersen, S., \& Liu, M. (2003). Teachers' beliefs about issues in the implementation of a student-centered learning environment. Educational 
Technology Research and Development, 51(2), 57.

Pratiwi, W. A. (2012). Diskriminasi perempuan dalam berita harian Surya: Kajian Wacana Kritis. Surakarta: FKIP Universitas Muhammadiyah Surakarta.

Rasman, R. (2018). To translanguage or not to translanguage? The multilingual practice in an Indonesian EFL classroom. Indonesian Journal of Applied Linguistics, 7(3), 687-694.

Saddhono, K., \& Rohmadi, M. (2014). A Sociolinguistics Study on the Use of the Javanese Language in the Learning Process in Primary Schools in Surakarta, Central Java, Indonesia. International Education Studies, 7(6), 25-30.

Savignon, S. J. (2008). Interpreting communicative language teaching: Contexts and concerns in teacher education. Yale University Press.

Savignon, S. J. (2018). Communicative competence. The TESOL
Encyclopedia of English Language Teaching, 1-7.

Tanveer, M. (2007). Investigation of the factors that cause language anxiety for ESL/EFL learners in learning speaking skills and the influence it casts on communication in the target language. University of Glasgow, Scotland.

Van den Bogaerde, B., \& Baker, A. (2005). Code mixing in mother-child interaction in deaf families. Sign Language \& Linguistics, 8(1-2), 153176.

Wardhaugh, R. (2011). An introduction to sociolinguistics (Vol. 28). John Wiley $\&$ Sons.

Waris, A. M. (2012). Code switching and mixing (Communication in Learning Language). Jurnal Dakwah Tabligh, 13(1), 123-135.

Yulia, Y. (2014). An evaluation of English language teaching programs in Indonesian junior high schools in the Yogyakarta province. 